THE WORLD BANK ECONOMIC REVIEW, VOL. I 5, NO. I 55-80

\title{
Flight Capital as a Portfolio Choice
}

\author{
Paul Collier, Anke Hoeffler, and Catherine Pattillo
}

\begin{abstract}
This article sets flight capital in the context of portfolio choice, focusing on the proportion of private wealth that is held abroad. There are large regional differences in this proportion, ranging from 5 percent in South Asia to 40 percent in Africa. The authors explain cross-country differences in portfolio choice using variables that proxy differences in the risk-adjusted rate of return on capital. They apply the results to three policy issues: how the East Asian crisis affected domestic capital outflows; the effect of the International Monetary Fund-World Bank debt relief initiative for heavily indebted poor countries on capital repatriation; and why so much of Africa's private wealth is held outside the continent.
\end{abstract}

In this article we estimate the stock of flight capital held abroad and compare it with the stock of real (nonfinancial) capital held within a country. This is of interest for two reasons, one at the aggregate level and the other at the level of the individual agent.

At the aggregate level, many of the problems commonly associated with capital flight are more closely associated with large proportions of real wealth held abroad than with the magnitude of annual outflows. First, there are large differences in the shares of wealth held abroad. In the regions with the most severe capital flight, the phenomenon has cumulatively accounted for a major reduction in the real capital stock per worker, with concomitant effects on income. Second, the concern that capital flight erodes the domestic tax base is more specifically an argument that a large share of private wealth held abroad reduces the domestic tax base. Third, the potential for capital flight repatriation depends on the share of wealth held abroad and how changes in policies affect expectations of risk-adjusted returns such that desired portfolio allocations change.

At the level of the individual agent, wealth held abroad reflects a portfolio choice, like the decision to hold any other asset. Typically, the decision as to how much of a particular asset to hold will be determined both by the relative attraction of the asset and by the amount of wealth. Similarly, the amount of

Paul Collier is with the Development Research Group at the World Bank; Anke Hoeffler is with the Centre for the Study of African Economies, Oxford University; and Catherine Pattillo is with the Research Department at the International Monetary Fund. Ms. Hoeffler's participation was funded by the Department for International Development of the Government of the United Kingdom. The authors would like to thank Eduardo Borensztein, Stijn Claessens, David Dollar, Michael Dooley, and Flemming Larsen for comments.

(C) 2001 The International Bank for Reconstruction and Development / THE WORLD BANK 
wealth held abroad will be determined both by the relative attractions of domestic and foreign assets and by the overall endowment of wealth. Thus, the decision problem is the allocation of a stock of assets. To date, however, empirical studies of capital flight usually have not analyzed it as reflecting the choice of a stock of foreign assets held as part of a stock of wealth. Instead, they have focused on the annual flow. This has reflected not a mistake of specification but rather a lack of data on stocks, both of capital flight and of overall private wealth. An exception is Cline (1995), who estimates the stock of flight capital for six Latin American countries and the Philippines and then compares it with the stock of some liquid domestic financial assets.

The innovation of this article is to build estimates of the stock of private flight capital and the stock of total private real wealth for 50 countries. These stocks are combined to estimate the proportion of total real wealth held abroad. This portfolio choice then becomes the dependent variable, which we explain in terms of national endowments and national policies.

Section I discusses the data and presents descriptive statistics on portfolio choices by region. Section II reviews the literature on capital flight and develops a framework for analyzing flight capital as a portfolio choice. In section III we test the framework, using data for 1970-90, and establish the determinants of portfolio choice. Section IV develops three applications. First, we investigate the impact of the deterioration in East Asian risk ratings following the recent currency crises on East Asian portfolio choices. Second, we investigate the effect of the heavily indebted poor countries (HIPC) debt relief initiative on portfolio choices: to what extent will forgiveness of public debt induce private capital repatriation? Finally, we investigate why Africa has had so much capital flight relative to other continents. Section V concludes.

\section{Portfolio Choices by Region}

The estimation of portfolio choices requires comparable measures of the stock of flight capital and the stock of private wealth. We discuss these two measures in turn and then aggregate them at the regional level.

\section{Measuring the Stock of Flight Capital}

The literature discusses a number of choices involved in the measurement of capital flight as a flow (see, in particular, Claessens and Naudé 1993). ${ }^{1}$ The World

1. Claessens and Naudé (1993) present estimates of capital flight using the four most common approaches: (1) the residual approach (used by the World Bank, Morgan Guaranty, and Cline); (2) measuring the stock of unreported assets (Dooley's method); (3) hot money measures (Cuddington 1986); and (4) measuring trade misinvoicing. The flows we term World Bank estimates are the authors' variant of the World Bank measure. They show that although the Dooley and residual measures differ greatly in conceptual approach, a Dooley measure of the flow of capital flight can also be obtained using a residual method. In section IV we show that our results are robust to calculating our capital flight stocks using the different measures of capital flight. See appendix III in an earlier version of this paper (Collier, Hoeffler, and Pattillo 1999). This version also contains other, more detailed appendices. 
Bank calculates capital flight using a variant of the residual method in which outward capital flight occurs when sources of funds exceed uses of funds. Sources of funds include all net official inflows and the net flow of foreign direct investment, and uses of funds include the current-account deficit and additions to reserves. ${ }^{2}$ In our estimation of stocks, we take the World Bank estimate of flows as our starting point. However, this series estimates capital flight only from the capital account of the balance of payments; it omits any capital flight through misinvoicing of trade. We add trade misinvoicing to the World Bank figures. Another departure from the World Bank concept of capital flight is that we do not deduct private nonguaranteed debt. That is, our concept uses gross rather than net private assets. The rationale for this is that behavioral claims and offsetting liabilities are not equivalent to the absence of claims, partly because the claims and the liabilities generally do not refer to the same agents.

To convert these flows into stocks requires an assumption as to the rate of return. We apply the interest rate on U.S. Treasury bills. A problem is that the net flow of apparent flight capital is sometimes negative. This can occur for two reasons. First, previous flight capital might be repatriated. Second, agents might borrow internationally. Clearly, this second phenomenon is conceptually distinct from capital repatriation and needs to be distinguished from it empirically. Following the World Bank methodology, we treat all the stocks of flight capital as being zero at the start of our period of observation, 1970. However, following Cline (1995) we count the stock of flight capital as becoming positive in the first year that the flow of capital flight becomes positive. In effect, we treat early years of negative flows as the accumulation of debts that are not reduced by subsequent capital flight. Our flight capital stocks are thus gross of indebtedness.

If flows subsequently turn negative, we treat it as the repatriation of capital. In this we slightly depart from Cline, who assumes that only half of the flow is repatriation, the other half being foreign investment. Because foreign investor capital inflows are separately and generally fairly accurately recorded in the balance of payments, Cline's adjustment seems unwarranted. Although we thus count negative net capital outflows as capital repatriation, we do not allow the stock of flight capital to fall below zero, consistent with our distinction between capital repatriation and foreign borrowing. Hence, a country that had an annual net flow during the first five years of $-3,-4,+3,-1$, and -5 would, by our measure, have a stock of flight capital in each of these years (before allowing for interest) of $0,0,3,2$, and 0 .

The flight capital stocks are converted to real 1985 U.S. dollars to make the figures comparable to our private capital stock measures.

\section{Measuring the Stock of Private Wealth}

We measure the stock of private wealth as the sum of flight capital as measured above, private real capital stock, and quasi-money. To measure the real private

2. Most of the data comes from the balance of payments. For net official external borrowing, however, World Bank debt data are used, because they are likely to be more accurate. 
capital stock, we first obtain a measure of the aggregate capital stock from the flows of past investment, following the method of King and Levine (1994). We estimate the initial capital stock for 1960 and use the perpetual inventory method to obtain annual values for the capital stock for 1960-90. ${ }^{3}$ We then disaggregate this total capital stock into its public and private components. The starting point is the public investment data from Easterly and Rebelo (1993), which we combine with World Bank data on gross domestic investment to calculate private investment. We adjust the public and private investment shares to be comparable to Penn World Tables data by using the ratio of gross domestic investment in domestic currency in 1985 to purchasing-power-parity-adjusted investment in 1985. Thus, our measure of private domestic wealth is in units of 1985 dollars at U.S. relative prices and so is directly comparable to our measure of flight capital.

We work with two concepts of private wealth. The first is private real wealth, which is the sum of the private real capital stock and the stock of flight capital. At the aggregate level, it is the allocation of private wealth between these two components that is important for income and growth. The second concept is private total wealth, which is the sum of private real wealth and quasi-money. Quasi-money is only one component of the financial wealth of private agents, however, it is the only one for which satisfactory data could be obtained for a reasonable sample of countries. It should be noted that important components are omitted, notably domestic bonds and pension claims.

Because the importance of these components differs systematically between regions, our regional wealth measures contain an unavoidable element of bias. Similarly, to the extent that some components of real wealth, such as subsistence livestock (which may be atypically important in Africa) and jewelry (which may be atypically important in South Asia), tend to be underestimated in national accounts, we can expect spurious differences between regions. Furthermore, the mapping from (observed) investment to (unobserved) wealth may differ systematically because of unobserved differences in depreciation rates between regions. For example, Africa might have atypically high depreciation rates. However, if regional biases are substantial, they will show up in our subsequent regression analysis in the form of significant and large regional dummy variables. In fact, only one such dummy is significant, namely, that for Latin America. This suggests that for other regions our measurement biases are not, in aggregate, substantial.

\section{Flight Capital Portfolio Choices by Region}

Table 1 summarizes the descriptive statistics for each region. The table includes only 50 countries, so no region is covered comprehensively. The most complete data is for Sub-Saharan Africa, for which 22 countries are included. For each region, the figures for capital (and real wealth) per worker are the sum of the capital (wealth) over the countries covered, divided by the sum of the work force

3. Although there are some existing capital stock measures available, using the King and Levine method allowed us to calculate capital stocks for a larger number of countries and an extended time period. 
Table 1. Private Wealth and Its Composition by Region, 1990 (1985 US\$)

\begin{tabular}{lcrrrrr}
\hline & $\begin{array}{c}\text { Public } \\
\text { capital } \\
\text { per } \\
\text { worker }\end{array}$ & $\begin{array}{c}\text { Private } \\
\text { wealth } \\
\text { per } \\
\text { worker }\end{array}$ & $\begin{array}{c}\text { Private } \\
\text { capital } \\
\text { per } \\
\text { worker }\end{array}$ & $\begin{array}{c}\text { Capital } \\
\text { flight } \\
\text { per } \\
\text { worker }\end{array}$ & $\begin{array}{c}\text { Capital } \\
\text { flight } \\
\text { ratio }\end{array}$ & $\begin{array}{c}\text { Estimated } \\
\text { output } \\
\text { loss (\%) }\end{array}$ \\
\hline Sub-Saharan Africa & 1,962 & 1,758 & 1,062 & 696 & 0.40 & 0.16 \\
Latin America & 8,576 & 19,362 & 17,439 & 1,923 & 0.10 & 0.04 \\
South Asia & 2,008 & 1,930 & 1,840 & 90 & 0.05 & 0.02 \\
East Asia & 4,505 & 10,331 & 9,704 & 627 & 0.06 & 0.02 \\
Middle East & 4,985 & 6,030 & 3,708 & 2,322 & 0.39 & 0.16 \\
\hline
\end{tabular}

Source: Authors' calculations.

in the same countries. Similarly, the flight capital ratio is the sum of flight capital for the region divided by the sum of private real wealth. The regional data should be treated with some caution. As noted, the coverage is limited to a minority of countries within each region and so may not be representative. Furthermore, there are large differences within each region.

The table shows four striking results. First, the differences between regions in private capital per worker are far larger than those in public capital. Second, by 1990 Africa was remarkably short of private capital, both absolutely and relative to public capital. In absolute terms it had barely half that of South Asia, the next most capital-scarce region. In relative terms, it had less private capital per dollar of public capital than any other region. Third, and most remarkably, Africa had the highest incidence of capital flight. Despite its capital scarcity, it slightly exceeded even the Middle East in the high proportion of private wealth held abroad: 40 percent of private portfolios were held outside the continent. Were Africa able to attract back this component of private wealth, the private capital stock would increase by around two thirds. Fourth, East Asia had a very low proportion of private portfolios held abroad, despite having a high level of private wealth. In view of the recent capital flight from the region, this is of some interest, suggesting that before the crisis East Asian wealth holders were unusual in the extent to which they retained their wealth domestically.

We estimate the implications of these differential portfolio choices for the level of output in each region. For this we estimate production functions that distinguish between private and public capital stocks. The regression is estimated as a cross-section relationship using period averages for 1980-90. The dependent variable is the log of gross domestic product (GDP), and the explanatory variables are the logs of the public and private capital stocks and the log of the labor force. Unobserved country-specific effects are proxied by the residuals from a Solow growth model to control for differences in technology across countries (Hoeffler 1998). All variables in the regression are highly significant, and the coefficients on the inputs sum to unity. For the present purpose, the important coefficient is that on private capital stock, namely, 0.40 . In table 1 , we use the 
coefficient on private capital to convert the estimated loss of domestic private real wealth into an estimated loss of GDP. Thus, Africa is estimated to have a level of GDP 16 percent lower than it would have if it had been able to retain its private wealth.

Our production function has another important implication. It distinguishes between the contributions of private and public capital stocks and finds that the coefficient on private capital stock, at 0.40 , is significantly larger than that on public capital stock, 0.24 . The implication is that capital flight is disproportionately damaging because it is the loss of private capital: it requires almost $\$ 2$ of public capital to offset the loss of $\$ 1$ of private capital. In Africa the loss of private capital per worker was $\$ 696$, so that it would have required $\$ 1,160$ of public capital to offset this loss. Because the actual public capital stock per worker was only $\$ 1,962$, around 60 percent of the public capital stock was in effect simply offsetting private capital flight.

\section{Modeling Capital Flight}

Although the view of capital flight as part of a portfolio allocation decision is implicit in much of the theoretical and empirical literature, it has not been investigated explicitly. Empirical models have analyzed the determinants of the flows of capital flight, not capital flight as a share of wealth. Based on portfolio considerations, however, the models often include interest differentials in explaining flows of capital flight. Theories have focused on tax and tax-like distortions that lower returns and add risk to domestic financial and physical assets, leading to capital flight, and on how often these risks are related to foreign borrowing.

Our starting point is a standard portfolio model, which Sheets (1995) presents as applicable to the capital flight decision. Capital flight arises from portfolio diversification incentives, return differential incentives, and relative risk incentives. Is capital flight explicable in the same manner as, say, allocating a portfolio across domestic bonds and equities, that is, in terms of a standard portfolio model? It is likely that the standard model will need to be modified and broadened. We review theories of capital flight to determine what special features would need to be added to a standard portfolio choice problem to reflect the particulars of allocating wealth to capital flight and domestic investment.

In one of the first theoretical models, Khan and Haque (1985) show that twoway capital flows, private capital flight occurring simultaneously with private foreign borrowing, can arise in a model where domestic and foreign investors face an asymmetric risk of expropriation. ${ }^{4}$ Domestic investors face a higher risk of expro-

4. Much of the literature has been concerned with explaining two-way capital flows, private capital flight occurring simultaneously with private or public foreign borrowing. This phenomenon is not easy to rationalize within standard theoretical models of optimal borrowing decisions. Although this issue is not important for our inquiry, we will be interested in the nature of the causal relationship between foreign borrowing and capital flight. The issue of rationalizing two-way capital flows is thus a prior question to causality - that is, why do foreign borrowing and capital flight occur at the same time? 
priation, so they invest abroad, and domestic investment is consequently financed with foreign funds. Dooley (1988) also focuses on the notion that domestic and foreign investors face asymmetric risk but broadens the source of the risk to the wide range of implicit taxes, generated by, say, rapid inflation or exchange rate depreciation. A fiscal shock may lead to increased government reliance on the inflation tax, which erodes the value of domestic financial assets and leads residents to acquire foreign assets. Foreign investors could be attracted by the fall in prices (increase in yields) as domestic residents liquidate their domestic securities. Foreigners face less risk because they are often able to get claims denominated in foreign currency, and these have explicit or implicit government guarantees.

The capital flight literature has built on these early theoretical models, essentially extending them in three directions. First, the risk of expropriation has been generalized to the risk of high taxation and related to large foreign borrowing. In most of these models, capital flight is subject to herding-as more capital flees, the expected per-capita tax liability increases and heightens the incentives for further capital flight. Second, political economy models have endogenized the reasons why governments may levy punitively high and variable taxes on domestic assets. Third, public finance models have focused on the effects of capital income taxation that varies de facto by residence and source, explaining capital flight and domestic investment financed with foreign borrowing.

We focus on the first category of models, because they have implications for empirical work, and briefly mention the other categories. In Eaton (1987), the expectation of increased tax obligations created by the potential nationalization of private debt generates capital flight. In his simplest model, private borrowers can invest their own and borrowed funds abroad, where they earn less than domestic investment projects. But the borrower escapes the obligation to repay the loan or to pay taxes. Potential nationalization of private debt implies that the flight of the capital of any one borrower increases the tax obligations of remaining borrowers. In one equilibrium, borrowers invest domestically and loans are repaid, and in another there is capital flight and default on foreign loans. Eaton and Gersovitz (1989) analyze a similar type of capital flight herding generated by anticipated tax obligations when the government borrows abroad to finance public goods. In a macroeconomic model, Ize and Ortiz (1987) show that when fiscal rigidities create difficulties for servicing foreign debt, private capital flight is encouraged by foreign borrowing because there is an expectation of higher domestic asset taxation to service future debt.

Capital flight in Schineller's (1993) model is subject to a similar type of herding, but it is not related to foreign debt. Returns to the domestic asset are stochastic because of political risk. Government taxes domestic returns to finance a given expenditure requirement, and so the per-capita tax rate is endogenous and depends on the number of investors who do not flee to the foreign asset. When transactions costs to changing the investment position are added, there is a range of inaction where capital flight will not be repatriated, although the expected domestic returns are favorable. 
Another type of model of capital flight explores why domestic agents face high and uncertain risks of explicit and implicit taxation of domestic assets. Alesina and Tabellini (1989) consider a model in which different government types with conflicting distributional goals randomly alternate in office. The uncertainty over future fiscal policies leads simultaneously to capital flight, low domestic investment, and the occurrence of large external debts. Overborrowing occurs because the current government does not fully internalize the future costs of servicing the debt. In Tornell and Velasco (1992), the government is the clearinghouse of the interests of various groups, and the interest group game results in confiscatory policies. If different groups have the ability to extract transfers from government, each group effectively has common access to the others' capital stocks. Capital flight offers an asset that may have a lower return, but its return can be privately appropriated. Finally, examples of capital flight models that focus on the different tax treatments for resident and nonresident holders of domestic assets include Dooley and Kletzer (1994) and Razin (1991).

The nature of the foreign debt-capital flight relationship has been controversial both in the literature and for international lenders and country governments. In the models discussed above, two different types of causal linkages have been considered. In Eaton's model, the inflow of foreign resources provides both the resources and a possible motive for capital flight. Boyce (1992) calls this debtfueled capital flight, as distinguished from debt-motivated capital flight that is the focus of some other models. The models above that consider debt-motivated capital flight focus on the channel through which high levels of foreign debt create expectations of heavy future asset taxation. It is also possible that there is no causal relationship between foreign debt and capital flight, but rather an indirect linkage. In Alesina and Tabellini (1989), for example, uncertainty about the type of future government generates capital flight, large foreign debts, and low domestic investment. ${ }^{5}$

Finally, it may be that the causality runs in the other direction, from capital flight to foreign debt. Boyce distinguishes flight-driven external borrowing from flight-fueled external borrowing. In the former, the drain of domestic resources lowers investment and generates demand for replacement funds from the government and private sectors, which external creditors may be willing to supply given the lower risks of heavy asset taxation they face. When external borrowing is fueled by capital flight, residents deposit capital abroad and the depositor obtains a loan from the same bank. This "round-tripping" allows the domestic investor to arbitrage the yield and risk differential between resident and external capital. ${ }^{6}$

5. Another example of an indirect linkage is Blejer and Ize (1989). Uncertainty over adjustment efforts leads to capital flight, low investment, and the sudden withdrawal of new foreign financing that accompanied the debt crisis.

6. For the Philippines, Boyce (1992) finds evidence for both debt-fueled capital flight and flightfueled external borrowing. Ajayi (1997) notes that no relation between debt and capital flight was found for a sample of Sub-Saharan African countries, although the methodology and results are not reported. 


\section{Implications for an Empirical Portfolio Model of Flight Capital}

To determine what special features relevant to the allocation of wealth to capital flight and domestic investment should be added to a standard portfolio model, we consider the theoretical models together with the general empirical patterns of capital flight experienced largely in the 1970s and 1980s.

The general empirical evidence on country-by-country macroeconomic policy and capital flight patterns suggests that pronounced capital flight occurs when a country experiences severe macroeconomic imbalances and the risks of punitive domestic asset taxation increase rapidly (Schineller 1997). Many countries experienced episodes of large sudden changes in capital flows, which seem related to indications that policies were unsustainable. These very large increases in capital flight suggest that standard return differentials based on equilibrium relationships will not account for the size of the capital movements, because asset returns will not adequately reflect the large increase in policy-oriented risks.

The standard portfolio model suggests two key incentives for capital flight: after-tax domestic returns adjusted for expected depreciation that are lower than after-tax foreign returns, and domestic returns that have higher volatility or risk than foreign returns. Our first modification to the standard model is the idea that the expected risk-adjusted relative returns will not be well captured by interest differentials, actual tax rates, and expected depreciation based on actual depreciation of the official exchange rate, as well as differential return volatilities. The theoretical models point out that one of the most important determinants of the expected future asset tax rate is the level of foreign debt. Expected depreciation may be better related to the degree of overvaluation of the real exchange rate. Historical return volatilities may not be a good guide to the expected riskiness of domestic assets during periods of severe policy and structural imbalances as well as political uncertainty. Below we discuss empirical proxies that represent risk-adjusted return differentials in this broader fashion.

We make a second modification because the models above point to the importance of contagion or herding in capital flight. Empirically, these models imply that in the portfolio decision of an individual investor, the expected after-tax returns on domestic investment would depend on the expected aggregate level of capital flight (or, alternatively, the available domestic capital base subject to taxation). An implication for aggregate capital flight portfolio shares is that the determinants of capital flight may have different effects when the capital flight share is small compared with when it is large. For example, a particular expected tax rate may have only small effects on the incentive for capital flight when the share of capital flight in aggregate portfolios is small. However, as capital flight increases, the same expected tax rate could imply a much higher per-capita expected tax liability given the lower domestic asset tax base, and thus have a larger influence on capital flight. This reflects the herding notion that as capital flight increases, the incentives for further flight increase. 
Third, foreign assets are much more liquid than domestic physical capital or claims on domestic physical capital. A model that considers the liquidity of alternative assets would imply that return differentials should be augmented by a liquidity premium. In addition, if domestic investment is more irreversible, then continuing to hold foreign assets even when domestic returns have become more favorable can be optimal due to the "option to wait" for future news about domestic returns.

\section{Determinants of Flight Capital Portfolio Shares}

In section I we developed measures of private portfolio choice as of 1990 for 50 countries and showed that at the regional level there were striking differences in choices. In section III we will attempt to explain these differences. To do so, we first develop a framework for analyzing the choice between holding assets domestically and abroad. Although such a framework may potentially involve many considerations, our purpose is to test our approach through measurable proxies for the theoretical concepts. We therefore limit the analysis to those factors that are amenable to measurement and include a discussion of empirical proxies for each concept. We consider factors that influence our broad concept of rates of return and the risks associated with each asset.

The rate of return on foreign assets can be assumed to be the same for all asset holders, and so relative returns differ only because of differences in domestic rates of return. The domestic private rate of return on capital, $r$, is assumed to be determined by four factors: the endowment of capital relative to labor, $k$; the rate of taxation of capital, $t$; anticipated changes in the real exchange rate, $e$; and the policy environment, $p$. The four factors determine the productivity of capital for a given capital/labor ratio

$$
r=r(k, t, e, p) .
$$

Although there are circumstances in which the return on capital will not decline in response to a rise in the aggregate capital/labor ratio, it is nevertheless reasonable to assume that, conditional on the policy environment, it will do so. Recall from table 1 that there are very large differences in the total capital stock (public plus private) per worker between regions. We would expect that, other things equal, this would imply that the rate of return on capital would be higher in the capital-scarce regions. Of course, the lack of capital in a region may be partly or wholly the result of other differences. In a world of fully mobile capital without risk, the rate of return on capital would be equalized, and so differences in capital/labor ratios would reflect underlying differences in production functions (or other endowments). However, the fully mobile capital model still utilizes the assumption of diminishing returns to capital: capital is withdrawn from unproductive regions and invested in productive regions until returns are equalized as a result of diminishing returns. To reduce the problem of endogeneity, we measure the capital/labor ratio for each country as of 1980 , using it to predict the portfolio choice in 1990. Most capital flight has occurred after 1980. 
Although the capital/labor ratio affects the overall return on capital, private portfolio decisions reflect only private returns. The main divergence between social and private rates of return is due to taxation. Because capital once installed is largely irreversible, owners of capital will be concerned not just with current rates of taxation but with expected future tax liabilities. A good measure of an important part of these liabilities is the foreign indebtedness of the economy. We proxy this by the ratio of foreign debt/gross national product (GNP).

Domestic and foreign assets are denominated in different currencies. Hence, to the extent that changes in the real exchange rate can be anticipated, the overall anticipated rate of return on foreign assets will include currency appreciation or depreciation. In competitively determined currency markets information may be used efficiently so that exchange rate changes cannot be systematically predicted, but in many developing countries official exchange rates have been considerably misaligned. During periods when the real exchange rate is overvalued, private agents have an incentive to move assets abroad because they can anticipate depreciation in some future period. We proxy this by the Dollar index of real exchange rate misalignment (Dollar 1992). A high level of misalignment will lower the return on domestic investment through various routes. Hence, any effect of the index on portfolio choice should be interpreted as a composite of the effect of anticipated changes in the exchange rate and of the effect of misalignment on the rate of return on investment. Similarly, the ratio of foreign debt/ GNP will also partially proxy the policy environment. A high level of foreign debt to GNP is likely to reflect a history of poor use of public resources: the ratio is high because of a lack of growth.

In addition to the expected rate of return on an asset, wealth holders must consider its implications for portfolio risk, which is determined by the individual riskiness of the asset and its covariance with the rest of the portfolio. Foreign assets can be regarded as a relatively safe asset, the absolute degree of risk being similar for all asset holders, whereas the covariance with domestic assets is usually low. Thus, the proportion of the portfolio held abroad, $f$, will depend on both the return on domestic assets relative to foreign assets, $r$, and their riskiness relative to foreign assets, $v$ :

$$
f=f(r, v) .
$$

A composite measure of the relative riskiness of domestic investment is the Institutional Investor risk rating for a country. This is generated by a poll of informed banking opinion twice a year and is scaled 0-100 (0 being the highest risk). Although the risk rating is a broad measure of country risk geared toward foreign investment and sovereign lending, many of the factors considered influence the climate for domestic investment. One factor that influences the risk ratings is indebtedness. The Institutional Investor ratings and the ratio of debt/ GNP have a correlation coefficient of -0.45 . Corruption is sometimes discussed as an indicator of asset riskiness. A high incidence of corruption may make legitimate assets vulnerable, and corruptly acquired wealth may be more secure 
outside the country. We use the International Country Risk Guide measure of corruption, averaged for the 1980s.

The five observable explanatory variables are the capital/labor ratio, foreign debt, the Dollar distortion index, the Institutional Investor risk rating, and the corruption index. We introduced these variables as individually proxying the underlying analytic explanatory variables. However, the observable variables are more properly interpreted as collectively proxying the risk-corrected rate of return on domestic investment, rather than as individually proxying its components. In particular, the country risk ratings contain information from the other explanatory variables so that, for example, the Dollar distortion index affects capital flight partly directly and partly through its effect on the risk ratings. To establish the full effect of the other variables, we first regress the risk ratings on the other explanatory variables, all of which are significant. We then use the residuals of the regression of the risk ratings, rather than the ratings themselves, in the flight capital regression. Thus, the coefficient on the Dollar distortion index shows the combination of both its direct effect on capital flight and its indirect effect via the risk ratings.

\section{Results}

Throughout the analysis, we use two dependent variables, the proportion of private total wealth held abroad and the proportion of private real wealth held abroad. Both variables are measured as of 1990, the most recent date for which all data are available. In principle, because private agents make their portfolio choices by considering all their components of wealth, the dependent variable that most closely approximates the decision problem of the private agent is flight capital as a proportion of private total wealth. However, there are three reasons why the alternative measure of flight capital as a proportion of private real wealth might be preferred. First, the only component of private financial wealth that can be measured on a comparable basis for a reasonable sample of countries is quasi-money. The addition of this single component of financial wealth might result in an inferior estimate of total private wealth than using the complete data on real private wealth as a proxy. Second, demand for the two relatively illiquid assets, domestic real capital and flight capital, might be more closely related than that for quasi-money. Third, at the aggregate level of the real economy, domestic private financial assets either directly net out or are claims on the government, which can only meet them by future taxation of the private sector. The only allocative decision at the aggregate level is between domestic real capital and flight capital.

Full data on the explanatory variables are available for 42 of the 50 countries for which we have data on the dependent variables. The first explanatory variable is the endowment of capital per worker (private plus public) in 1980. Because most capital flight is post-1980, this considerably reduces potential endogeneity. The other explanatory variables are the Dollar distortion index, the residuals of the 
Institutional Investor risk ratings, and the ratio of debt/GNP. For each of these, we use the annual average of the variable for 1980-89. The rationale for using the average over the decade instead of the end-period value is that, because the costs of reversing investments are sometimes high, the portfolio composition at any one time reflects past decisions. Furthermore, we argued above that theoretical models point to the potential endogeneity of the foreign debt ratio and that the endogeneity of the real exchange rate distortion index should also be considered. By utilizing previous period averages, we reduce this problem of endogeneity.

For 12 of the countries in the sample, the measured stock of capital flight in 1990 is zero. We therefore experimented with tobit models. However, the regressions failed the test for normality of the error term, implying that tobits are inconsistent. We therefore switched to ordinary least squares; the results are very similar in the two approaches. Because the regression includes as an explanatory variable a generated regressor, the standard errors have been corrected for its effect as well as for heteroskedasticity. We investigated nonlinear relationships through the introduction of squared terms and allowed for regional effects through dummies. Only the dummy for Latin America was significant.

Based on our discussion of how liquidity considerations could affect portfolio allocation, we also investigated whether financial depth, measured as the ratio M2/GDP, was a determinant of the capital flight share. The variable was usually insignificant. When debt is omitted as an explanatory variable, financial depth becomes marginally significant at the 10 percent level but is wrongly signed; hence, we exclude it from the regressions. We investigated a range of governance indicators proxying the strength of property rights, such as risks of expropriation and repudiation of contracts. Neither these nor (somewhat surprisingly) the corruption index was significant. We attempted to proxy the mean and variance of portfolio returns by including the rate of growth and variance of GDP. These are rather crude proxies for the underlying concepts and were not significant. The insignificant variables were excluded from the final regressions.

Table 2 reports the results for flight capital as a proportion of private real wealth, and table 3 reports the results for flight capital as a proportion of private total wealth. Overall, the two dependent variables reveal a very similar story, although the fit is usually better for flight capital as a proportion of private real wealth. The addition of quasi-money increases the importance of exchange rate overvaluation, which may reflect the greater liquidity of quasi-money. In the following discussion, we focus on table 2 . We regard our real wealth measure as a better proxy for total private wealth than that generated by the inclusion of quasi-money. Furthermore, our applications in section IV rely on the aggregate choice between domestic real private investment and flight capital. Overall, all variables have the expected sign and credibly sized coefficients and the fit of the regression is good.

In regression 2, the capital/labor ratio is significant at 1 percent. However, its effect is not very large. An addition of $\$ 10,000$ per worker, which is a very large increase by the standards of developing countries, increases the proportion of private wealth held abroad by only 5 percentage points. 


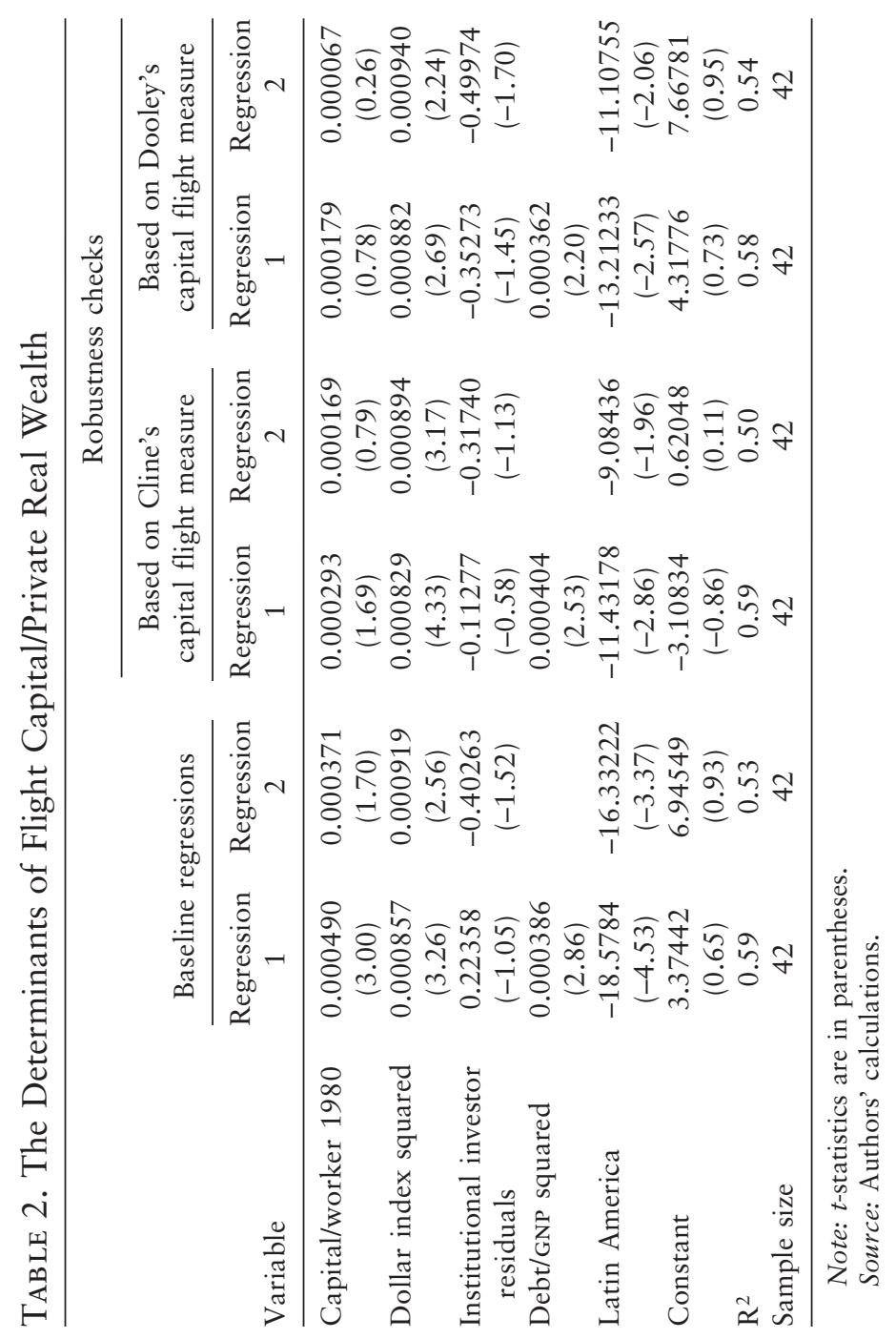




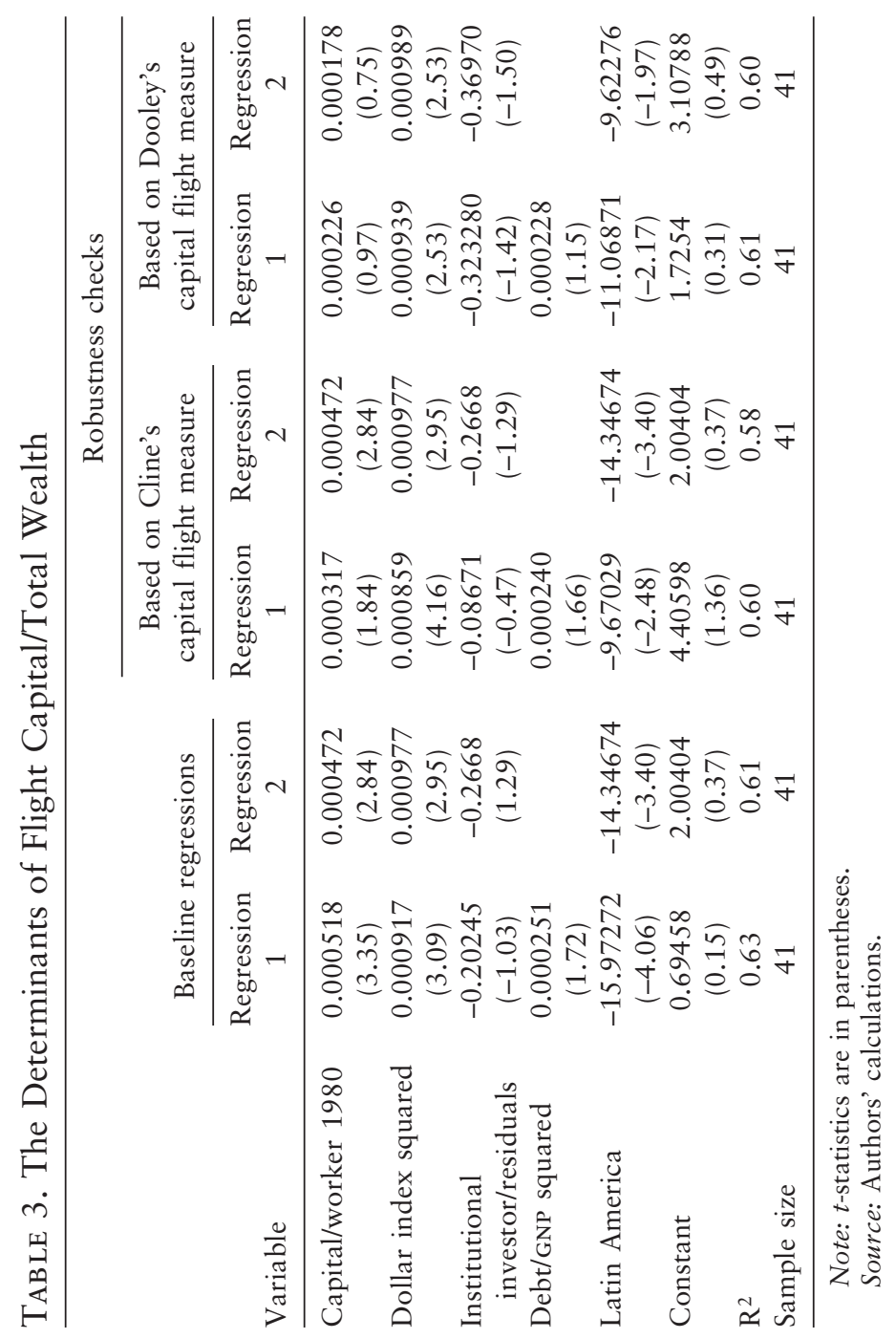


The Dollar distortion index is significant at 1 percent and has a large effect. The index is constructed so that a value of 100 represents a normal set of relative prices. We investigated whether values of the index below this level had different effects from values above 100, but we found no difference. The effect is best captured by the square of the index, suggesting that extreme overvaluations are most damaging. For example, a change in the index from 100 to 200 increases the proportion of the portfolio held abroad by 26 percentage points. A value of 200 is high, but by no means the peak of the index: Over the 152 countries for which the index has been measured, the peak value is 1,311 .

The ratio of foreign debt/GNP is significant at the 1 percent level. However, the variable fits best as a square of the ratio and becomes economically important only at very high levels of indebtedness. For example, at the level of indebtedness agreed by the European Union for its "convergence criterion," namely, 60 percent, debt only reduces the proportion of wealth held domestically by 1.4 percentage points compared with a debt-free economy. By contrast, moving from the highest indebtedness found in the sample, 297 percent, to the level of 60 percent would reduce the proportion of wealth held abroad by 33 percentage points.

The residual of the Institutional Investor rating has the expected negative sign but is insignificant. When the residuals are reestimated so as to exclude debt from the ratings regression and debt is correspondingly excluded from the flight capital regression, the risk rating residuals become close to significant, as reported in table 2.

We now consider the robustness of the results to two different measures of capital flight. Specifically, we use the Cline method, which, like our own, uses a residual approach but with different assumptions, and the Dooley method, which seeks to measure the stock of privately held foreign assets that do not generate income reported to the authorities. As shown in table 2, on the Cline measure, the Institutional Investor ratings residuals are insignificant; on the Dooley measure, they are significant when debt is excluded. Thus, each of the three approaches leads to a somewhat different conclusion as to whether the risk ratings simply proxy the other variables or have some independent effect. However, although the significance levels of the risk ratings residuals vary substantially between the three measures, the coefficients on all the variables are reasonably stable.

\section{Three Applications}

This section develops three applications of the regressions: the effect of the East Asian crisis on capital flight, the effect of the HIPC debt initiative on capital repatriation, and why Africa has had so much capital flight.

\section{The East Asian Crisis}

Although capital outflows have obviously played a central role in the East Asian crisis, to date the focus has been on the repatriation of short-term foreign capi- 
tal. Here we consider the longer-term response of domestic portfolios. We show that in steady state the domestic adjustment is likely to be large.

The East Asian crisis has resulted in a sharp fall in investor confidence in some countries in the region. We utilize the observed decline in the Institutional Investor risk ratings between March 1997 and March 1999 to estimate the impact on the reallocation of East Asian portfolios into capital flight. A study of the risk ratings finds that, controlling for their underlying determinants, they have a high degree of persistence (Haque, Mark, and Mathieson 1999). Thus, the large deterioration in the ratings during the period is likely to persist for longer than the fundamental causes of the crisis.

Our objective is to estimate the likely medium-term portfolio adjustment that would occur were the deterioration in the risk ratings indeed to prove persistent despite a recovery in the fundamentals. We therefore multiply the change in the risk ratings by the coefficient that describes the pure risk ratings effect, abstracting most importantly from exchange rate effects. This is given by the coefficient on the ratings residuals in the second column of the baseline regression of table 2. We should note two important caveats. First, we are using results derived from a cross-section analysis to derive the consequence of an event. Because the crosssection result tells us nothing about dynamics, it can at best suggest the long-run effect of an event. The results should therefore be interpreted cautiously, as showing how portfolios might eventually adjust were the changes in the risk ratings persistent. Second, the coefficient as estimated in the baseline model has a wide confidence interval.

Table 4 shows the estimated increase in capital flight for the four most severely affected East Asian countries: Thailand, Korea, Malaysia, and Indonesia. The first seven rows in the table show the deterioration in the Institutional Investor risk ratings. The main deterioration in the risk ratings occurred in the six months subsequent to March 1998. The eighth row shows our estimate of private real wealth as of 1996, the most recent year for which an estimate is currently feasible. The final rows show our prediction of the increase in the capital flight component of portfolios, first in millions of dollars and then as a share of GDP. Altogether, the four countries are predicted to experience a capital outflow of approximately $\$ 240$ billion.

The predicted steady-state domestic capital outflow of $\$ 240$ billion can be compared with the actual reversal to date in total private capital flows, domestic plus foreign, which can be observed from changes in the balance of payments. Between 1996 and 1998, what had been a large net foreign private capital inflow turned into a large net outflow, reflecting both capital repatriation by nonEast Asians and capital outflows by East Asians. The total of this as of end 1998 was around $\$ 100$ billion. Because we only estimate capital outflows by East Asians, we are only predicting one component of the observed total. However, the full $\$ 240$ billion predicted domestic portfolio adjustment might only take place over several years. 
Table 4. Capital Flight in Response to the East Asian Crisis

\begin{tabular}{|c|c|c|c|c|}
\hline Indicator, period & Thailand & Korea & Malaysia & Indonesia \\
\hline \multicolumn{5}{|l|}{ Risk rating } \\
\hline March 1997 & 61.1 & 71.4 & 67.5 & 51.6 \\
\hline March 1998 & 52.3 & 64.4 & 64.5 & 49.9 \\
\hline September 1998 & 47.5 & 53.6 & 59.0 & 32.9 \\
\hline March 1999 & 46.9 & 52.7 & 51.0 & 27.9 \\
\hline $\begin{array}{l}\text { Change, March 1997- } \\
\text { March } 1998\end{array}$ & -8.8 & -7.0 & -3.0 & -1.7 \\
\hline $\begin{array}{l}\text { Change, March 1997- } \\
\text { September } 1998\end{array}$ & -13.6 & -17.8 & -8.5 & -18.7 \\
\hline $\begin{array}{l}\text { Change, March 1997- } \\
\text { March } 1999\end{array}$ & -14.2 & -18.7 & -16.5 & -23.7 \\
\hline \multicolumn{5}{|l|}{$\begin{array}{l}\text { In billions of U.S. dollars } \\
\text { at current prices }\end{array}$} \\
\hline Private real wealth in 1996 & 639.4 & $1,093.3$ & 357.6 & 993.8 \\
\hline \multicolumn{5}{|l|}{$\begin{array}{l}\text { Predicted change in portfolios } \\
\text { (in billions of U.S. dollars at } \\
\text { at current prices) }\end{array}$} \\
\hline March 1997-September 1999 & -36.6 & -82.4 & -23.8 & -94.9 \\
\hline $\begin{array}{l}\text { March 1997-September } 1999 \\
\text { (using 95\% confidence intervals) }\end{array}$ & $(-85.3,12.2)$ & $(-192.0,27.4)$ & $(-55.4,7.9)$ & $(-221.2,31.6)$ \\
\hline $\begin{array}{l}\text { As percent of } 1996 \text { GNP } \\
\text { March 1997-September } 1999\end{array}$ & -20.3 & -17.1 & -25.1 & -44.1 \\
\hline $\begin{array}{l}\text { March 1997-September } 1999 \\
\text { (using 95\% confidence intervals) }\end{array}$ & $(-47.2,6.7)$ & $(-39.9,5.7)$ & $(-58.5,8.4)$ & $(-102.7,14.7)$ \\
\hline
\end{tabular}

Notes: Private wealth in our underlying data set is calculated as discussed in section I for 1990 and is measured at 1985 prices. As in table 5, we first convert this to 1990 prices by multiplying by 1.214 , the increase in the U.S. CPI over the period. We then assume that the ratio of private wealth to GNP was the same in 1996 as in 1990, and so scale up the 1990 private wealth figure by GNP in 1996/ GNP in 1990. The effect on private portfolios is then calculated as the change in the risk rating, multiplied by 0.00403 (the coefficient on the risk rating residuals in table 2, regression 2) multiplied by private wealth in 1996. Note that this is quite distinct from any flight of foreign-owned assets from the four countries. As a proportion of GNP, the largest loss would be borne by Indonesia, capital flight exceeding 40 percent of GNP.

Source: Authors' calculations.

\section{The HIPC Initiative}

The new debt relief initiative of the International Monetary Fund and the World Bank, the HIPC arrangement, will lower the foreign debt/GNP ratio for eligible countries. Currently, within our sample, Uganda, Côte d'Ivoire, Burkina Faso, Guyana, and Mozambique have passed the "decision point" at which it is determined that the country has met the eligibility criteria. The debt/GNP ratio will decline for these countries, although by widely varying amounts. Table 5 shows the effect on private portfolios, applying the debt coefficient from table 2. Recall that this captures the full effect of indebtedness, both directly and via the risk ratings. We convert this effect into an estimated dollar amount commensurate with the 1996 debt and GNP figures used by assuming that the ratio of private wealth/GNP observed for 1990 also applied in 1996. 


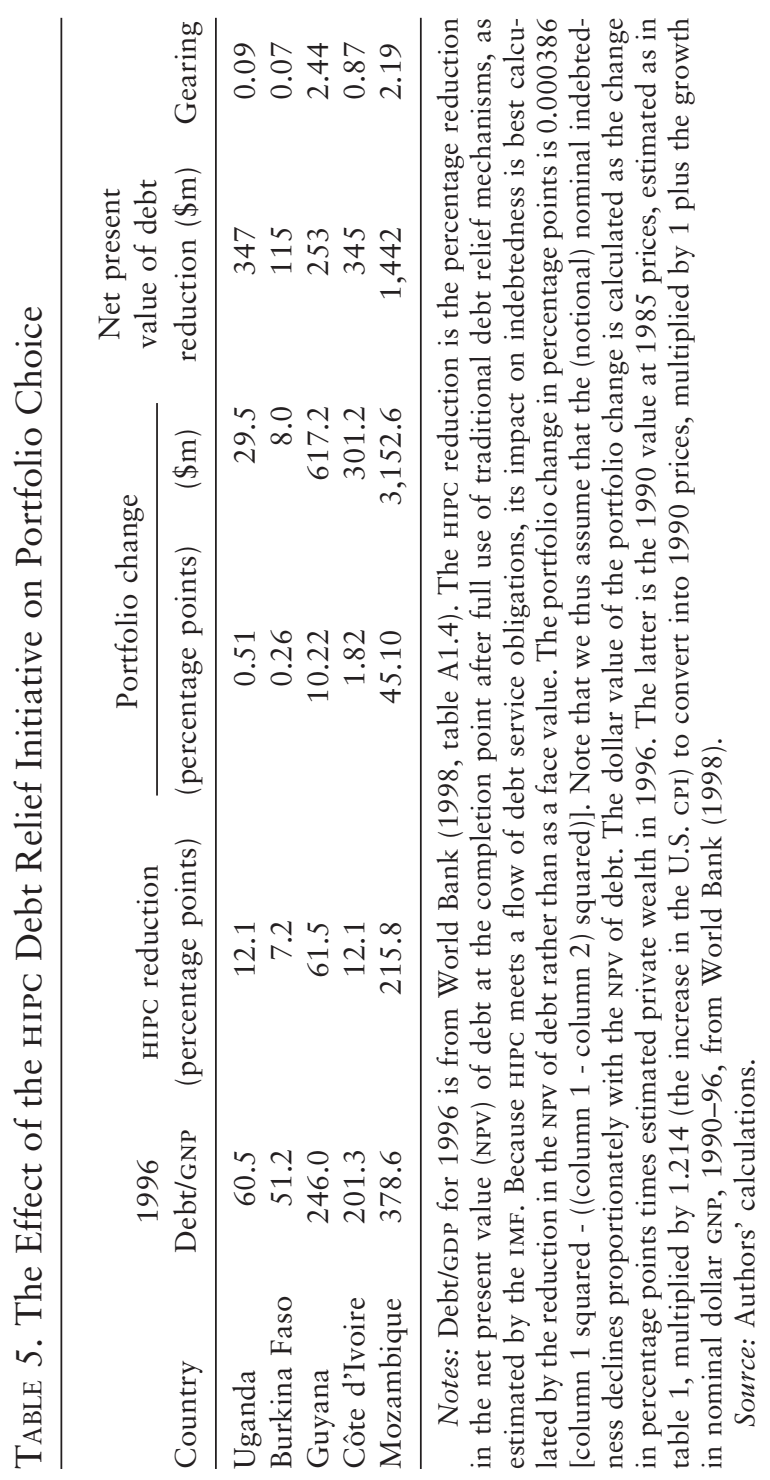


Thus, for example, for Guyana debt forgiveness under the HIPC initiative is estimated to reduce indebtedness by 25 percent. We estimate that this reduction would reduce the proportion of Guyanese private wealth held abroad by 10.2 percentage points. Under these assumptions, Guyanese private wealth holders would repatriate $\$ 617.2$ million. Because the net present value of the debt reduction is only $\$ 253$ million, in this instance each dollar of public funds is augmented by $\$ 2.44$ of repatriated private funds. Debt relief to Guyana has such a high gearing because Guyana is very highly indebted, while the marginal efficiency of debt relief increases with indebtedness, and because it has a high level of private wealth relative to GDP. By contrast, Burkina Faso and Uganda have far lower gearing because both the above factors work against them.

\section{Why Africa Has Had So Much Capital Flight}

The most remarkable result of the study is that Africa has such a high level of private capital held abroad, namely, 40 percent. We now utilize the regression results to explain this phenomenon. When an Africa dummy variable is introduced into the regression, it is neither large nor significant. Hence, the variables included in the regressions fully account for the exodus of private capital. Table 6 decomposes African capital flight into its causes by explaining the difference between African and East Asian portfolio choices. Why have East Asians placed a much smaller proportion of their wealth abroad than Africans have?

The first explanatory variable, the endowment of capital per worker, actually deepens the puzzle. As shown in table 1, Africa has a far lower capital endowment than East Asia, and the regressions find that, other things equal, capital scarcity reduces capital flight. East Asia has had little capital flight despite being relatively well endowed with capital, whereas Africa has had massive capital flight despite being poorly endowed. Both regressions imply that the difference in capital endowments would have induced Africans to hold domestically around 1.5 percentage points more of their portfolios than East Asians hold. That Africa has such a high proportion of its wealth abroad despite being capital scarce is an indicator of how much effect the other variables have had.

African real exchange rates have been substantially overvalued relative to East Asian exchange rates. The average value of the Dollar index in the African sample is 140 compared with 83 for the East Asian sample. Recall that the effect of exchange rate overvaluation is nonlinear, being determined by the square of the index rather than by its level. Hence, the mean values of 140 and 83 convert into squared values of 19,572 and 6,885 . However, even this understates the effect on portfolio choice because some African countries have had extremely overvalued exchange rates. As a result, the difference between the means of the squares of the index, which is what matters for the regression, is even greater than that between the square of the means. The mean of the squares of the index is 3.32 times greater in Africa than Asia, whereas the square of the mean is only 2.84 times greater. Both regressions imply that this large difference would have induced Africans to hold domestically around 14 percentage points less of their portfolios than East Asians. 


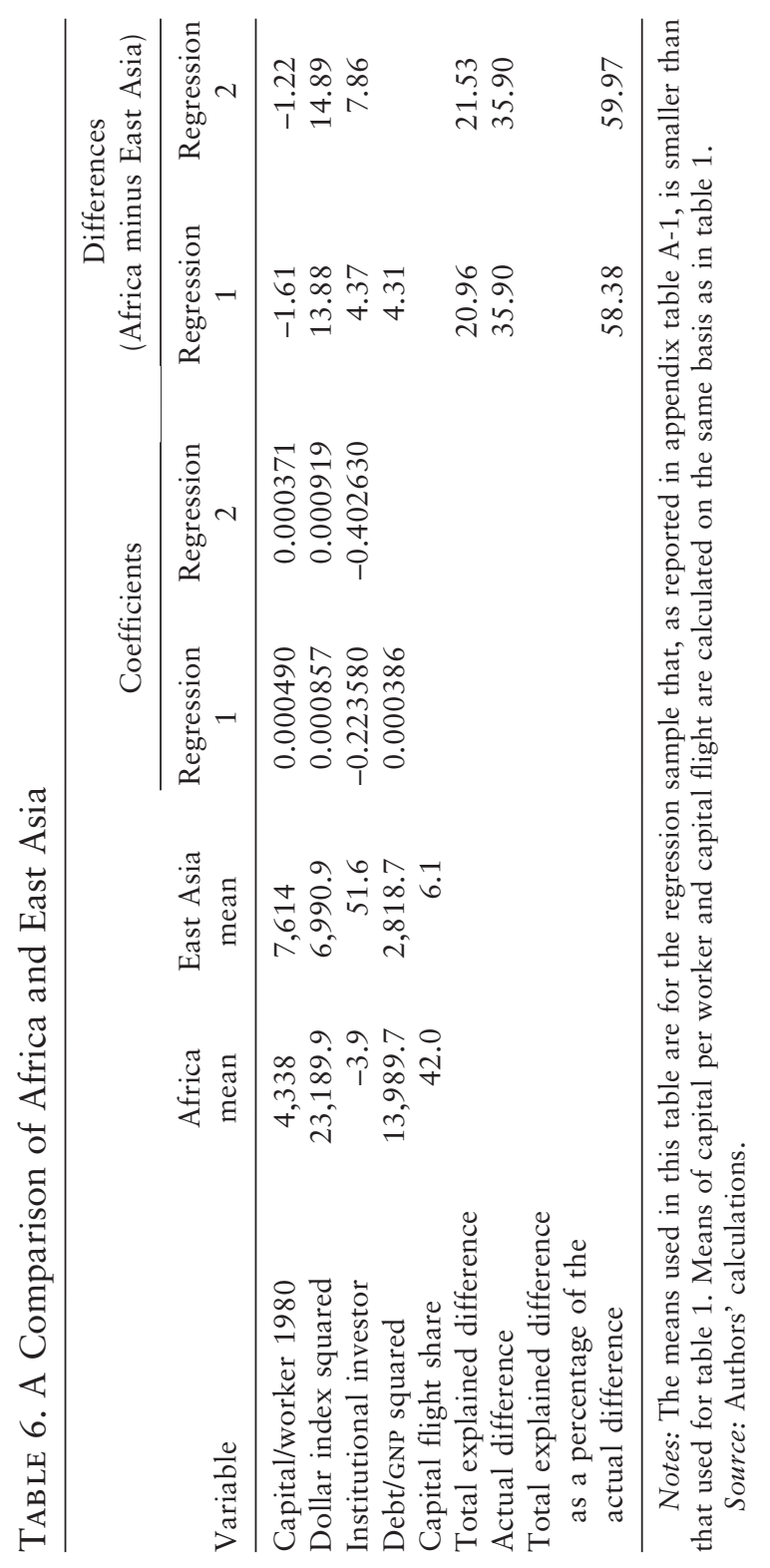


Africa has been rated by international investors as the riskiest continent. The average value of the Institutional Investor index was only 22 for Africa, compared with 52 for East Asia. Recent events in East Asia suggest that these ratings might not have been accurate predictors of actual risks. Haque, Mark, and Mathieson (1999) show that although the ratings are explicable on economic fundamentals, there is a large and significant Africa dummy: Africa is regarded as more risky than is warranted by the fundamentals. In our regressions, we do not use the level of the risk ratings but rather the residuals from values predicted from the other explanatory variables. However, this pattern of Africa being disadvantaged relative to East Asia is true for these residuals as well as for the levels. Africa's risk rating is lower than would be accounted for by exchange rate overvaluation and indebtedness, whereas East Asia's rating is higher. The effect of this difference in risk ratings residuals between Africa and East Asia on portfolio choice has been substantial. The regressions imply that the risk ratings have increased African capital flight relative to East Asian by between 4 and 8 percentage points of private portfolios.

Africa has been much more heavily indebted than East Asia. On average, the ratio of debt/GNP is 95 percent in the Africa sample and only 51 percent in the East Asia sample. However, as with exchange rate overvaluation, even this difference understates the effect on portfolio choice because it is the square rather than the level of the variable that is important. Although the average African country has been heavily indebted, some countries have been extremely heavily indebted. Hence, the mean of the squares is 4.96 times greater for Africa than for East Asia, whereas the square of the mean is only 3.45 times greater. The regression with debt included implies that indebtedness has increased African capital flight relative to East Asian capital flight by 4 percentage points of private portfolios.

\section{Conclusion}

In this article we have attempted to set flight capital in the context of a portfolio choice, focusing on the proportion of private wealth that is held abroad. For 50 countries as of 1990, we were able to construct estimates of private domestically held capital on a comparable basis and estimates of the stock of capital flight. The sum of these two stocks yields private real wealth, of which the stock of flight capital is then expressed as a proportion. We found that there were large regional variations in the proportion of the portfolio held abroad, with the highest proportion being for Sub-Saharan Africa, where 40 percent of private wealth was abroad. By contrast, East Asia had only 6 percent of its private wealth abroad.

We attempted to explain these differences. We set out a simple framework for portfolio choice based on the rate of return on domestic assets and their riskiness relative to foreign assets. We then proposed measurable proxies for the variables used in the theory and tested it on the data set. Other things being equal, the higher is the endowment of capital per worker, the higher the capital flight. 
Exchange rate overvaluation, foreign indebtedness, and investor risk all increase the proportion of the portfolio held abroad.

We applied the results to three questions. First, we used the estimated effect of the risk ratings to calculate the effect of their deterioration in response to the East Asian crisis on East Asian portfolios. We estimated that the four most severely affected East Asian countries would eventually lose around $\$ 240$ billion of domestic wealth as a result of the deterioration in risk between March 1997 and March 1999. Second, we used the estimated effect of foreign debt to calculate the effect of the HIPC debt relief initiative on capital repatriation. We find that the effect will vary massively among Hipc-eligible countries. Finally, we considered why Africa has had so much capital flight. The fact that Africa has by far the lowest capital per worker makes its high capital flight all the more distinctive. However, an Africa dummy added to the regression is insignificant. Three variables explained African capital flight: exchange rate overvaluation, adverse investor risk ratings, and high indebtedness. We decomposed the large difference in capital flight between Africa and East Asia into these components.

\section{APPENDiX}

\section{Sample for Table 1}

- Sub-Saharan Africa: Benin, Burkina Faso, Burundi, Cameroon, Congo, Côte d'Ivoire, Gabon, Gambia, Ghana, Kenya, Mali, Mauritania, Mauritius, Mozambique, Nigeria, Rwanda, Senegal, Seychelles, Togo, Uganda, Zambia, Zimbabwe.

- Latin America and the Caribbean: Argentina, Brazil, Chile, Colombia, Costa Rica, Dominican Republic, Ecuador, El Salvador, Guatemala, Guyana, Honduras, Jamaica, Mexico, Nicaragua, Paraguay, Peru, Venezuela.

- South Asia: Bangladesh, Pakistan, Sri Lanka.

- East Asia: Indonesia, Malaysia, Philippines, South Korea, Thailand.

- Middle East and North Africa: Egypt, Syria, Tunisia.

\section{Sample for Tables 2 and 3 (Regressions)}

The same countries as for table 1, with Portugal and Turkey, and excluding Benin, Burkina Faso, Burundi, Gambia, Ghana, Guyana, Mali, Mauritania, Rwanda, and Togo.

\section{Calculation of the Capital Flight Ratio}

Table A-1 demonstrates the calculation of the capital flight ratio using the data for Mexico as an example. Column 1 contains the trade misinvoicing data, and column 2 contains the World Bank measure of flows of capital flight. We sum the two and cumulate the flows into stocks (where at time $t$ the capital flight stock is the sum of the capital flight flow in $t$ plus the capital flight stock in $t-1$ plus interest, using U.S. Treasury bill rates). We deflate the total by the U.S. 
Table A-1. Calculation of the Capital Flight Ratio for Mexico (millions of US dollars)

\begin{tabular}{|c|c|c|c|c|c|c|}
\hline Year & $\begin{array}{c}\text { Trade } \\
\text { misinvoicing } \\
(1)\end{array}$ & $\begin{array}{l}\text { World Bank } \\
\text { capital flight } \\
\text { flows } \\
\text { (2) }\end{array}$ & $\begin{array}{l}\text { Capital } \\
\text { flight } \\
\text { stocks } \\
(3)\end{array}$ & $\begin{array}{l}\text { Ratio of } \\
\text { private capital } \\
\text { to total } \\
\text { capital } \\
\text { (4) }\end{array}$ & $\begin{array}{l}\text { Private } \\
\text { capital } \\
\text { stock } \\
(5)\end{array}$ & $\begin{array}{c}\text { Capital } \\
\text { flight } \\
\text { stocks/private } \\
\text { wealth } \\
(6)\end{array}$ \\
\hline 1971 & -39.3 & -225.6 & & 0.64 & $211,402.9$ & \\
\hline 1972 & 49.8 & -179.4 & & 0.65 & $229,728.8$ & \\
\hline 1973 & 12.4 & 778.2 & $1,915.0$ & 0.64 & $247,337.0$ & 0.01 \\
\hline 1974 & 363.9 & 688.0 & $4,155.7$ & 0.64 & $269,251.6$ & 0.02 \\
\hline 1975 & -165.8 & 157.9 & $4,013.0$ & 0.63 & $287,362.7$ & 0.01 \\
\hline 1976 & -351.6 & $2,629.2$ & $8,290.9$ & 0.62 & $307,111.4$ & 0.03 \\
\hline 1977 & 194.5 & $8,829.6$ & $24,219.4$ & 0.62 & $324,539.7$ & 0.07 \\
\hline 1978 & -935.4 & $1,474.5$ & $25,007.8$ & 0.60 & $336,712.2$ & 0.07 \\
\hline 1979 & -614.4 & $3,158.9$ & $28,494.8$ & 0.59 & $357,575.2$ & 0.07 \\
\hline 1980 & $-1,460.8$ & $5,435.0$ & $33,205.1$ & 0.58 & $385,674.1$ & 0.08 \\
\hline 1981 & -808.5 & $6,495.3$ & $41,075.8$ & 0.57 & $418,850.6$ & 0.09 \\
\hline 1982 & -64.2 & $6,762.9$ & $50,301.4$ & 0.57 & $441,400.3$ & 0.10 \\
\hline 1983 & -395.6 & $10,825.5$ & $64,194.7$ & 0.59 & $466,402.0$ & 0.12 \\
\hline 1984 & $-1,259.6$ & $4,439.9$ & $70,739.2$ & 0.61 & $490,850.1$ & 0.13 \\
\hline 1985 & $1,484.1$ & $3,954.8$ & $78,868.6$ & 0.63 & $520,841.6$ & 0.13 \\
\hline 1986 & $2,448.2$ & $3,957.2$ & $88,363.4$ & 0.64 & $539,472.1$ & 0.14 \\
\hline 1987 & $1,590.0$ & $10,587.9$ & $101,642.2$ & 0.68 & $577,231.4$ & 0.15 \\
\hline 1988 & $3,880.2$ & $5,294.7$ & $112,619.3$ & 0.74 & $636,423.1$ & 0.15 \\
\hline 1989 & $1,985.8$ & $-8,313.1$ & $110,643.8$ & 0.76 & $672,908.9$ & 0.14 \\
\hline 1990 & $5,336.2$ & $-3,403.5$ & $114,442.1$ & 0.77 & $699,248.8$ & 0.14 \\
\hline
\end{tabular}

Source: Authors' calculations.

consumer price index to obtain real capital flight stocks in 1985 dollars (column 3). Next, we turn to the calculation of domestic wealth. As described in the text, we calculate the ratio of private/total capital (column 4) and multiply it by our capital stock estimates (see below) to obtain the country's private capital stock in column 5. The country's private wealth is the sum of domestic private capital stock and the capital flight stocks, and the capital flight ratio is the ratio of capital flight stocks/total private wealth as given in column 6 .

\section{The Capital Stock Measure}

Following King and Levine (1994), we estimate an initial capital stock measure and use the perpetual inventory method to compute capital stocks, using investment data from Penn World Tables, version 5.6 (PWT 5.6).

\section{Independent Variables}

- Dollar's (1992) distortion index measures the extent to which the real exchange rate is distorted from its free-trade level. PWT 5.6 data are used to construct the index of a country's relative price level (RPL). The distortion 
index is a measure of the difference between the actual RPL and an RPL predicted by the country's endowments, proxied by GDP per capita.

- Institutional Investor risk ratings are based on evaluations from the staff of approximately the largest 100 commercial banks.

- Debt/GnP data are from the World Bank's World Data CD-ROM (1994).

- Capital/labor ratio. Capital is calculated as described above; the number of workers is from PWT 5.6.

\section{REFERENCES}

The word "processed" describes informally reproduced works that may not be commonly available through library systems.

Ajayi, S. Ibidayo. 1997. "An Analysis of External Debt and Capital Flight in the Severely Indebted Low Income Countries in Sub-Saharan Africa.” IMF Working Paper 97/68. Washington: International Monetary Fund.

Alesina, Alberto, and Guido Tabellini. 1989. "External Debt, Capital Flight and Political Risk." Journal of International Economics 27(3/4):199-220.

Blejer, Mario, and Alain Ize. 1989. "Adjustment Uncertainty, Confidence and Growth in Latin America after the Debt Crisis.” IMF Working Paper 89/105. Washington: International Monetary Fund.

Boyce, James K. 1992. "The Revolving Door? External Debt and Capital Flight: A Philippine Case Study." World Development 20(3):335-49.

Claessens, Stijn, and David Naudé. 1993. "Recent Estimates of Capital Flight.” World Bank Policy Research Working Paper Series, no. 1186, Washington, D.C.

Cline, William R. (ed.). 1995. International Debt Reexamined. Washington, D.C.: Institute for International Economics.

Collier, Paul, Anke Hoeffler, and Catherine Pattillo. 1999. "Flight Capital as a Portfolio Choice." IMF Working Paper 99/171, Washington, D.C.

Cuddington, John T. 1986. "Capital Flight: Estimates, Issues and Explanations." Princeton Studies in International Finance 58:1-44.

Dollar, David. 1992. "Outward-Oriented Developing Economies Really Do Grow More Rapidly: Evidence from 95 LDCs, 1976-1985.” Economic Development and Cultural Change 40:523-44.

Dooley, Michael. 1988. "Capital Flight: A Response to Differential Financial Risks." Staff Papers, International Monetary Fund 35(3):422-36.

Dooley, Michael, and Kenneth Kletzer. 1994. "Capital Flight, External Debt and Domestic Policies.” NBER Working Paper no. 4793, Cambridge, Mass.

Easterly, William, and Sergio Rebelo. 1993. "Fiscal Policy and Economic Growth." Journal of Monetary Economics 32(3):417-58.

Eaton, Jonathan. 1987. "Public Debt Guarantees and Private Capital Flight." World Bank Economic Review 1(3):377-95.

Eaton, Jonathan, and Mark Gersovitz. 1989. "Country Risk and the Organization of the International Capital Transfer." In G. Calvo, R. Findlay, P. Kouri, and J. Macedo (eds.), Debt, Stabilization and Development. Oxford, U.K.: Blackwell. 
Haque, Nadeem ul, Nelson Mark, and Donald J. Mathieson. 1999. "The Economic and Political Content of Risk Indicators.” In Paul Collier and Catherine Pattillo (eds.), Investment and Risk in Africa. London: Macmillan.

Hoeffler, Anke. 1998. Econometric Studies of Growth, Convergence and Conflicts. Ph.D. thesis, University of Oxford, Oxford.

Ize, Alain, and Guillermo Ortiz. 1987. "Fiscal Rigidities, Public Debt and Capital Flight." Staff Papers, International Monetary Fund 34(4):311-32.

Khan, Moshin, and Nadeem ul Haque. 1985. "Foreign Borrowing and Capital Flight: A Formal Analysis." Staff Papers, International Monetary Fund 32(4):606-28.

King, Robert G., and Ross Levine. 1994. "Capital Fundamentalism, Economic Development, and Economic Growth.” Carnegie-Rochester Conference Series on Public Policy 40:259-92.

Razin, Assaf. 1991. "Optimal Incentives to Domestic Investment in the Presence of Capital Flight.” Journal of International Economics 31(1-2):17-31.

Schineller, Lisa. 1993. "Hysterisis, Political Risk and International Capital Movements: Essays on Capital Flight.” Ph.D. thesis, Yale University, New Haven, Conn.

— 1997. "An Econometric Model of Capital Flight from Developing Countries." International Finance Discussion Paper no. 579, Board of Governors of the Federal Reserve System, Washington, D.C.

Sheets, Nathan. 1995. "Capital Flight from the Countries in Transition: Some Theory and Empirical Evidence.” International Finance Discussion Paper no. 514, Board of Governors of the Federal Reserve System, Washington, D.C.

Tornell, Aaron, and Andrés Velasco. 1992. "The Tragedy of the Commons and Economic Growth: Why Does Capital Flow from Poor to Rich Countries?" Journal of Political Economy 100(6):1208-31.

World Bank. 1998. Global Development Finance. Washington, D.C.: World Bank. 